\title{
Improving Training Impact Through Effective Follow-Up: Techniques and Their Application
}

Harry J. Martin

Cleveland State University, h.martin@csuohio.edu

Follow this and additional works at: https://engagedscholarship.csuohio.edu/bus_facpub

Part of the Organizational Behavior and Theory Commons How does access to this work benefit you? Let us know!

Publisher's Statement

This article is (c) Emerald Group Publishing and permission has been granted for this version to appear here: 10.1108/02621711011046495. Emerald does not grant permission for this article to be further copied/distributed or hosted elsewhere without the express permission from Emerald Group Publishing Limited.

\section{Original Published Citation}

Martin, H. J. (2010). Improving Training Impact Through Effective Follow-Up: Techniques and Their Application. Journal of Management Development, 29(6), pp. 520-534.

This Article is brought to you for free and open access by the Monte Ahuja College of Business at EngagedScholarship@CSU. It has been accepted for inclusion in Business Faculty Publications by an authorized administrator of EngagedScholarship@CSU. For more information, please contact library.es@csuohio.edu. 


\title{
Improving training impact through effective follow-up: techniques and their application
}

\author{
Harry J. Martin \\ Cleveland State University, Cleveland, Ohio, USA
}

\begin{abstract}
Purpose - This paper aims to describe a variety of cost-effective methods that employers can use to support training activities and promote the transfer of skills and knowledge to the workplace. These techniques work to positively impact the workplace environment through peer and supervisory support.

Design/methodology/approach - The application of action plans, performance assessment, peer meetings, supervisory consultations, and technical support is illustrated in two case examples.

Findings - Follow-up activities resulted in improved transfer and had positive quantitative and qualitative effects on operations and firm performance.

Practical implications - Billions of dollars are spent annually by organisations on employee training and management development. It is important that managers implement procedures that encourage transfer of learning in order to achieve greater training impact. The techniques discussed have wide application and significant effects on trainee motivation and workplace environment that are critical to success.

Originality/value - The paper provides an in-depth discussion of how to create peer support mechanisms that encourage training transfer. It also provides details on how organisations can engage managers in follow-up efforts.
\end{abstract}

Keywords Training, Management development, Training management

Paper type Case study

Billions of dollars are spent annually by organisations on employee training and management development. In the USA alone, this figure has been estimated to be from $\$ 55.8$ billion to as much as $\$ 200$ billion and is likely to increase (Arthur et al., 2003; Bunch, 2007; O'Leonard, 2008; Salas and Cannon-Bowers, 2001). While corporations are unlikely to add to spending on training and development in the current economic climate, governmental stimulus efforts include significant expenditures for worker retraining (Leonard, 2009). Every indication is that the need for employee development will continue given the increasing demands on organisations to boost productivity, keep pace with technological advances, meet competitive pressures, use team-based decision-making and problem-solving, streamline processes, and retain talent. Changes in economic forces and globalization also point to the importance of human resources and skilled "knowledge workers" as key sources of sustainable competitive advantage (Drucker, 1999; Drucker et al., 1997). The capacity of organisations to learn, adapt, and change is a critical component of competitiveness today with managers placing greater emphasis on processes that help companies become "learning organisations" (Gephart et al., 1996; Senge, 1995). 
To respond to this dynamic and ever changing environment, organisations both public and private must place increasing importance on learning and skill development. This considerable investment may bring employers a favorable return but rarely is the impact of this expenditure assessed (Bersin, 2006). Studies suggest that many training and development activities are implemented on blind faith with only the hope that they will yield results (Arthur et al., 2003; Broad and Newstrom, 1992; Robinson and Robinson, 1989). Seldom are training programs rigorously evaluated to determine their effect on the behavior or job performance of participants. One of the more optimistic estimates suggests that no more than 15 percent of learning transfers to the job (Cromwell and Kolb, 2004). Other studies of transfer rates find they typically average only in the 10 to 40 percent range (Baldwin and Ford, 1988; Burke and Hutchins, 2007; Fitzpatrick, 2001; Ford and Kozlowski, 1997). Therefore, it is important to explore methods that encourage transfer of learning in order to achieve greater training impact.

Our purpose is to describe a variety of cost effective methods that employers can use to support training activities and promote the transfer of skills and knowledge to the workplace. Although our focus is on follow-up techniques that create a more favorable environment for training transfer, a review of variables that affect transfer is warranted to provide a context for this discussion. Previous research has identified program design, trainee characteristics, and the workplace environment as key factors that influence transfer (e.g., Alvarez et al., 2004; Baldwin and Ford, 1988; Ford and Weissbein, 1997; Yamnill and McLean, 2001).

\section{Program design}

Proper design and delivery of a training program is a major contributor to the transfer of learning. If training is to have a sustainable impact on participant behavior, it must be designed to meet the needs of the learner and the organisation (e.g. Montesino, 2002; Olsen, 1998; Rossett, 1997). Important questions include: Are the objectives of the training understood and clearly communicated to the participants? Are the skills to be acquired similar to skills currently in use? Is the training perceived as relevant to the job currently being performed or objectives to be achieved? Have participants been involved in determining the content and design of the training program? Do participants believe they will have an opportunity to practice the skills or apply the knowledge gained? Will participants receive feedback on their performance or application and have the opportunity to make appropriate adjustments? Is the training location conducive to effective learning? Is the timing of the training appropriate and are job demands adjusted to allow for training? In short, program design should include a needs assessment, clear program goals that align the training with the strategic direction of the organisation, the involvement of key stakeholder groups, and dissemination of information that establishes the credibility of the program before it starts (Clark et al., 1993).

Proper conduct of the program builds on good training design. It is essential to maintaining the learner's interest in the training and motivation to put forth the energy required to acquire new skills (Axtell et al., 1997). Research shows that engaging trainees through exercises that apply the information and feedback during instruction allows learners to make adjustments in their behavior and gain insight into changes required (e.g. Burke et al., 2006). In particular, learning transfer for complex 
decision-making tasks is enhanced by the active involvement of the learner during training. A major reason properly designed training programs have greater success transferring to the workplace is that they improve the learner's cognitive understanding and retention of the content and build the learner's self-confidence and motivation to apply the training (Colquitt et al., 2000). These cognitive and motivational components help to facilitate the transfer and maintenance of learned behaviors (Wexley and Baldwin, 1986).

\section{Trainee characteristics}

A variety of learner characteristics have been studied in relation to transfer of learning. Two related characteristics that figure prominently in the literature are self-efficacy and employee motivation. Self-efficacy is concerned with the learner's self-confidence and belief in his or her ability to successfully acquire and transfer the target skill (Gist et al., 1991). Related to self-efficacy is the motivation or desire of the learner to change his or her behavior (Mathieu et al., 1992; Webster and Martocchio, 1993). Employers could improve effectiveness by training only those learners with a high level of self-efficacy and motivation but this is often not practical. Therefore, researchers have looked for ways to improve the confidence and motivation of trainees through activities before, during, and after the training.

Trainees with a high degree of self-efficacy tend to be more motivated learners and accomplish more (Chiaburu and Marinova, 2005). A direct link has been established between efforts to build the self-confidence of learners and the likelihood of their using skills on the job (Salas and Cannon-Bowers, 2001). This is one of the reasons for investing in good training design and preparing learners for training. Understanding the objectives of the training, its relevance to individual and organizational performance, and expectations for application can greatly enhance learner motivation (Montesino, 2002). Assessing individual performance and providing feedback prior to training can also have a positive impact on motivation. This is because a more realistic appraisal of skill is achieved through feedback than through self-evaluation alone. If properly presented, such feedback can stimulate confidence in the learner's ability to improve his or her performance through training (Salas et al., 1999).

\section{Workplace environment}

While much research has focused on program design and trainee characteristics in promoting learning transfer, attention has also been given to the influence of the workplace environment. Workplace environment includes such factors as managerial support, peer encouragement, adequate resources, opportunities to apply learned skills, technical support, and consequences for using training on-the-job (Burke and Hutchins, 2008; Colquitt et al., 2000; Kontoghiorghes, 2001; Lim and Morris, 2006; Rouiller and Goldstein, 1993; Tracey et al., 1995). Research has shown that removing barriers to application in the work environment is so important that training opportunities should be turned down by employees if proper follow-up support is not available (Rossett, 1997).

The attitude and behavior of an employee's supervisor is a particularly important element in skill application and transfer of learning. Managers can show support for training in a variety of ways ranging from simply allowing employees to attend the training to participating in the training itself as an instructor (Birdi et al., 1997; 
Brinkerhoff and Montesino, 1995; Broad and Newstrom, 1992; Burke and Baldwin, 1999). Supervisors signal whether the training is to be used and how quickly changes are expected. A supervisor who does not view the training as useful or relevant can easily undermine application in a variety of direct and covert ways. A supportive organizational climate is also communicated by how the work is designed and skill application rewarded.

Peer support enhances learning transfer both by improving employees' feelings of self-efficacy and by providing them with feedback and coaching. Peer support enhances learning transfer through the feedback, encouragement, problem-solving assistance, supplemental information, and coaching provided to trainees (Facteau et al., 1995; Hatala and Fleming, 2007) and may have a stronger influence on trainee transfer than supervisory support (Gilpin-Jackson and Bushe, 2007). Networking with peers and sharing ideas about skill application also helps promote skill transfer (Hawley and Barnard, 2005).

In summary, behavioral changes following training will be short-lived without activities to support transfer. These activities may occur in advance of the training to improve program design, motivate learners, or generate positive expectations; during training to demonstrate relevance and promote understanding of concepts and their application; or after training to create a more favorable workplace environment, provide feedback of results, and motivate effort toward change. Research suggests that both cognitive and behavioral components should be addressed if learned behaviors are to be effectively transferred and maintained on-the-job.

\section{Follow-up techniques}

Program design, trainee characteristics, and the workplace environment provide a context for transfer but the application of specific activities to follow-up training is also critical to success (Robinson and Robinson, 1989). It has been recognized that constraints and obstacles in the post-training environment can interfere with and limit the transfer of training (Tannenbaum and Yukl, 1992). Research has also found that the transfer climate and support provided to trainees are particularly important for transfer (Holton et al., 2000; Rouiller and Goldstein, 1993; Tracey et al., 1995).

In spite of this, Saks and Belcourt (2006) report that organizations rarely incorporate follow-up activities into their training programs. In addition, they recommend that organizations ensure a strong support network for trainees both before and after training. However, many organizations are unsure how to accomplish this. We have found several follow-up activities to be particularly useful in supporting transfer. They are action plans, performance assessment, peer meetings, supervisory consultations, and technical support.

Action plans are written documents completed by trainees during or immediately following training that specify how the trainee expects to implement learned skills on-the-job. These plans may be quite detailed and specific or brief and general. They frequently encompass both cognitive and behavioral components of the learning. They promote cognitive learning because they involve the learner more deeply in concepts and relationships and, thereby, promote greater insight and collateral learning. Behavioral components are involved since the learner must describe the actions to be taken, consider their impact on individuals and processes, and specify how improvement will be assessed (Broad and Newstrom, 1992; Tannenbaum and Yukl, 1992). 
Performance assessment encompasses activities undertaken to measure or observe the behavior of trainees in work settings following instruction. Numerous studies have identified follow-up assessment and evaluation as important aids to promoting transfer of learning (e.g. Salinger and Deming, 1982; Tyson and Ward, 2004; Yorks et al., 2007). Some advocate a strong emphasis on outcome measurement to guide the design and conduct of training programs. Not only does this approach improve the program and the ability of managers to see meaningful results, learner motivation is often increased through greater understanding of expectations for change and feedback on performance. While an expressed objective of training assessment is to help managers justify the cost of programs, an important outcome of assessment activities is often greater motivation to apply skills and increased transfer.

Peer meetings are periodic meetings of trainee groups following instruction and are usually facilitated by a professional staff employee or external consultant. At these meetings employees share examples of how they are applying the skills and information from the training, explain the impact of their application on operations and performance, and explore barriers to application and how they can be eliminated. These meetings promote transfer by improving the trainees' understanding of the material learned and by motivating action through direct encouragement and the examples given by other trainees (Baldwin and Ford, 1988; Tannenbaum and Yukl, 1992).

Supervisory consultations are designed to put the trainee's immediate supervisor into the role of coach or mentor to encourage skill application. One of the most important supports for training originates from supervisors and peers (Cromwell and Kolb, 2004). Supervisors play a key role in the post-training environment by giving trainees feedback, encouragement, reinforcement, and by providing opportunities to practice newly learned behaviors (Baldwin and Ford, 1988; Ford et al., 1992; Kraiger et al., 2004; Tannenbaum and Yukl, 1992). Securing the supervisor's involvement in the subordinate's development can be achieved in a variety of ways. However, a common element is the creation of specific opportunities for the subordinate and supervisor to meet to discuss the actions being undertaken by the trainee and for the supervisor to offer support and encouragement.

Technical support involves a variety of mechanisms established by an organisation to provide information and assistance to participants following a training program. This support often includes reference materials and additional information on training topics in written or electronic form. Technical support may also include access to in-house experts or advisors who are available to answer trainee questions and help problem-solve applications. Sometimes trainees meet with or have access to consultants or other outside advisors.

Substantial research confirms the importance of post-training activities to training transfer. However, many employers are uncertain how to accomplish this and practices vary widely (Hutchins, 2009). The following are two cases that demonstrate several of these follow-up activities. These examples show the importance of stimulating transfer of learning by improving trainees understanding of concepts as well as their self-confidence and motivation to take actions that apply the skills learned.

\section{Manufacturing company case}

Program context

The first case describes activities to follow-up a comprehensive training program for managers at a large manufacturing company in the Midwestern US. The organisation 
was in the process of shifting daily supervisory duties from company managers to hourly employees in self-directed work teams. The training program targeted the front-line managers and was designed to build the skills necessary to transition these managers from a traditional supervisory role to that of a process manager. Transfer of training was an important consideration from the beginning and was addressed through program design, trainee motivation, and workplace environment. It was determined that several training groups would attend one of 12 week-long sessions designed to have a significant impact on the attitudes and behavior of the front-line managers.

\section{Follow-up techniques}

Performance assessment. The evaluation plan for the project included the collection of performance ratings for all managers attending the training. A total of 237 managers participated in the program. These ratings were made by each manager's immediate superior. The ratings were obtained prior to training and at six weeks and three months following training.

A performance-rating instrument was developed especially for this project that assessed 13 separate dimensions:

(1) coaching;

(2) goal setting;

(3) goal acceptance;

(4) performance feedback;

(5) leadership style;

(6) use of influence;

(7) listening skill;

(8) managing change;

(9) meeting effectiveness;

(10) oral communication;

(11) project management;

(12) team building; and

(13) written communication.

Each of these skill dimensions was addressed specifically by a component of the training program.

The results of the assessment showed the program had a significant positive effect on trainee performance. A significant improvement in performance was observed three months following the training on each of the 13 dimensions assessed. This indicates that, in the eyes of the managers providing the ratings, the participants had demonstrated significant training transfer.

Peer meetings. Since the duties of front-line managers were changing significantly, a series of one-hour long peer meetings were scheduled with each training group to provide application support and motivational encouragement. Four meetings facilitated by an external consultant were scheduled with each training group between two and 12 weeks following their training session. During these meetings, managers were given the opportunity to: 
- discuss the results of their development efforts;

- share problems associated with implementing the skills;

- better understand the problems and pressures faced by other managers; and

- encourage each other's use of the skills on-the-job.

While not every trainee has a lot to say initially, many do and their success and enthusiasm eventually encourages even the most skeptical member to give the new skills a try. Once they do, they see the benefits of using the skills and success builds on success.

To better understand the impact of the program, an effort was made to assess the effect of the work environment on transfer. Specifically, the support of the company's general managers for the training program was assessed and comparisons made between divisions. Managers from 12 divisions participated in the program and each division was led by a general manager. The director of the training program and two of the firm's human resources department staff who had extensive contact with the general managers independently rated each manager according to how favorably they thought the manager viewed the program. These ratings were averaged and those scoring above the scale midpoint were judged as heading a division with a "favorable" climate and those scoring below the scale midpoint were judged as heading a division with an "unfavorable" climate. There was a high degree of agreement among the raters. Using this procedure, five divisions with 102 trainees were judged to have a favorable climate and seven divisions with 135 trainees were judged to have an unfavorable climate. With only a few exceptions, general managers did not make performance assessment ratings of trainees.

Results showed that trainees in divisions with a more favorable climate demonstrated significantly more transfer of learning. Trainees in favorable climates improved on each of the thirteen dimensions rated while those in unfavorable climates showed significant improvement on only seven of the 13 dimensions. These findings are consistent with previous research citing the importance of workplace climate for training transfer (Cromwell and Kolb, 2004).

Another interesting finding was related to the ability of the peer meetings to offset the negative effect of the trainees' climate. While attendance at peer meetings was encouraged, it was voluntary. Attendance was recorded with each manager attending between zero and four sessions. Of course, many factors influenced whether a manager attended these meetings. However, analysis of the performance data showed that those trainees in a division with an unfavorable climate who attended more peer meetings had a greater transfer of learning than those with a similarly negative climate who attended fewer meetings. A positive correlation was also observed between attendance and performance for trainees in a division with a favorable climate but the effect was not as strong.

Action plans. Another important activity to encourage transfer was the creation of personal action plans for each skill area. Resistance to change on the part of some trainees is formidable and they need encouragement to put the skills they learn into practice. To promote implementation of these skills, participants developed personal action plans for each of the main content areas of the program. These action plans served as guides for application of skills by requiring each participant to specify what he or she would do, with whom, and when to implement the concepts learned on-the-job. These plans did not have to be detailed and could be completed easily. Their main objectives 
were to clarify what each manager intended to do in his or her situation and increase the level of self-efficacy to improve the likelihood of behavioral change. The plans were not audited but managers were asked to report informally about their efforts at peer meetings and periodically questioned about their activities by their immediate supervisor and staff of the company's human resources department.

Supervisor consultations. An additional support activity to encourage training transfer was supervisor consultations. Here, each participant's immediate supervisor was required to meet with him or her to discuss action plans and progress with implementation. These meetings were scheduled three and six weeks following the subordinate's training session. The primary purpose of these meetings was to provide encouragement and support for application of the techniques learned. A secondary purpose was to encourage follow-up observations by managers to aid in making the performance ratings and for providing informal feedback to human resources staff and the program director on program impact.

\section{Qualitative impact}

Testimonials obtained from the trainees, their supervisors, and human resources staff indicated that a number of attitudinal and behavioral changes occurred as a result of the program. Prior to training, front-line managers were depressed and anxious about their future and role within the organisation. Following the program, attendees felt much better about the future. Morale was higher and greater optimism was expressed about changes occurring within the company.

Another commonly observed result was that front-line managers were communicating and working with a greater variety of peers than before the training. The commonality of experience and knowledge gained through the training encouraged greater cross department and division networking than had existed previously. Managers were found to be much more likely to work on projects in other areas, call and meet with colleagues in other functions, and even sit at different tables and eat with different groups in the company's cafeteria.

The newly defined job of process manager placed an emphasis on the development and management of projects to reduce costs and improve quality at the company. Accordingly, the training program included modules on goal setting, project management, and managing change. Many of the trainees initiated projects as a result of the peer meetings and action planning process that resulted in substantial cost reductions in some divisions. The company's vice presidents and president were impressed, indeed surprised, by the number of projects initiated and completed by the front-line manager group.

Prior to the training program, trust and communication between the front-line manager group and department and general managers was poor. The program addressed listening and oral and written communication skills but the intent was to apply these skills in interactions with employee teams and peers. Numerous examples were forthcoming, however, from the trainees and their supervisors noting improvements in communication between the trainees and upper management. While it is difficult to identify a single cause for this improvement, many supervisors and trainees said the supervisor consultations helped to increase understanding between front-line and more senior managers especially with regard to the responsibilities and contributions of each to performance improvement. 
In summary, the front-line manager training program had a number of positive quantitative and qualitative effects on company operations. However, it is unlikely that these effects would have been as pronounced without the performance assessment, peer meetings, actions plans, and supervisory consultations that were implemented to follow-up the training. Although this was not a controlled experimental study, the impact of peer meeting attendance and differences between favorable and unfavorable division climates provide additional support for this conclusion.

\section{Industrial supplier case}

Program context

The second case describes activities that encouraged training transfer in a different kind of program in a different context. The company is a worldwide supplier of engineered products and employs approximately 500 people in its North American division. The training program in question was designed for supervisors of hourly employees in the firm's primary manufacturing facility. As part of a corporate-wide reengineering effort, the facility was reorganised into five manufacturing units or cells. Concurrent with this change was an effort to implement more team-based decision-making and problem-solving in the facility. An important component of this program was a change in the role of production supervisors from a command and control model to one that emphasised coordination and facilitation. These supervisors were reassigned to one of the cells within the facility and given the title "unit coordinator." Engineering, warehouse, and material handling supervisors also received this title. A total of 12 coordinators were scheduled to attend a series of half-day meetings to discuss the transition and introduce them to contemporary management techniques that would assist them in their new role. Ten meetings were held, one per month, and facilitated by an external consultant.

\section{Follow-up techniques}

Boss-subordinate negotiations. While the coordinators generally enjoyed a high level of rapport and trust with unit managers in the facility, most reported to a different manager following the reorganization. Consultation with company executives indicated that an improved understanding between coordinators and their bosses would not only benefit training transfer but also reduce communication problems during the conversion. Therefore, a procedure was implemented in association with the training program to encourage dialog between the unit managers and unit coordinators.

Each manager and coordinator prepared a confidential memorandum to each other that described what the person "should do or do more of" or "do less or stop doing" to improve training transfer. The manager and coordinator exchanged memoranda and then met privately to discuss and clarify the content and agree on actions to be taken by each party. It was important to secure the active support of unit managers and for unit coordinators to feel they could influence their superiors to make the change more of a joint rather than unilateral process. The project director and vice president of operations informally monitored the process to ensure all parties treated the discussions in a positive and constructive fashion.

Action plans. Similar to the manufacturing company case, trainees were asked to develop a personal action plan following each training meeting. These plans were kept 
simple to encourage implementation by the coordinators. The plan consisted of writing a response to the following five questions:

(1) What will you do to implement a concept from today's session?

(2) When and with whom will you do this?

(3) What results do you expect and how will they be measured?

(4) When do you expect to see these results?

(5) What assistance or support will you need to implement your plan?

These plans were not submitted to the project director or senior managers but they were discussed in "supervisory consultation" and "technical support" meetings.

Supervisory consultations. To further encourage application of training by coordinators and to provide emotional and resource support, unit managers were asked to meet periodically with their coordinators to review action plans and encourage corrective action where necessary. Most managers met monthly with their coordinators while others combined this discussion with other operational meetings. While the frequency and format of these conversations varied, all unit managers discussed the implementation of action plans.

Technical support. Research has shown that learners who participate in follow-up meetings with instructors and peers after training are more likely to use the training effectively. Likewise, receiving feedback from a qualified observer on-the-job can enhance transfer of learning (Kluger and DeNisi, 1996; Wexley and Baldwin, 1986). In this situation, the project director scheduled monthly meetings individually with each coordinator to discuss training transfer. Typically, these meetings were one-hour in duration and focused on the coordinator's action plan for that month's training module. The project director provided technical support to the coordinators by helping them to better conceptualise their plans or diagnose problems with implementation. On occasion, the project director gave additional reading or resource material to coordinators.

Performance assessment. Behavior change on the part of coordinators was not rated numerically due, in part, to the wide variety of circumstances and priorities faced by the trainees. However, the company expected improvement in a number of indicators of operating effectiveness. Many factors influenced performance on these business indicators so improvements cannot be attributed solely to the effect of the training. However, actions of the unit coordinators clearly affected these operational measures.

During the training and six months following the program improvements were noted for all units including machine cycle times, indirect labor cost, scrap rate, return on sales, machine utilization (down) time, and lost days due to accidents. Each unit had specific productivity targets for the year known as "Full rate production" targets. One unit met and four of the units exceeded their yearly targets.

\section{Qualitative impact}

In addition to improved productivity and business performance indicators during this period, evidence suggested other positive effects of the coordinator training. As part of the firm's quality management process, employees and managers were encouraged to form teams to assess and propose improvements to various processes used in line and staff functions. Teams wishing to receive recognition for improvements submitted a project summary to the firm's quality council. Cost savings resulting from projects 
were estimated and awards given based on the dollars saved. A conservative estimate was that over $\$ 1$ million in costs were removed from the operations division by coordinator led teams during the year training was conducted. Two awards were presented to unit coordinators for projects yielding over $\$ 150,000$ savings each.

Other qualitative improvements were also observed in coordinator morale, self-confidence, and personal initiative. A decline in union grievances during this period was attributed, in part, to the improved leadership of the coordinators.

\section{Summary and conclusions}

Although these findings do not represent a rigorous test of the effectiveness of various follow-up techniques, they provide qualitative information that aids in understanding previous work on transfer. In addition, they support previous recommendations that managers consider training transfer issues in any development effort. The influence of program design, trainee characteristics, and workplace environment on transfer should be evaluated and strategies developed to improve transfer. The cases presented here show that workplace environment is especially important. The trainee's immediate supervisor, as well as other middle and upper-level managers, send important signals to trainees that can greatly encourage or discourage their efforts. Most training involves change and change creates anxiety that people seek to avoid. To help learners overcome anxiety and change their on-the-job behavior, managers must be actively involved and supportive. Peers can also serve as a source of encouragement and confidence building and can even help to mitigate an unfavorable climate. However, their influence will greater if superiors are supportive as well.

These cases illustrate that uncertainty reduction, self-efficacy, risk management, and trainee motivation can be addressed through proper follow-up activities. For example, supervisory consultations as implemented here help to reduce trainee uncertainty over expectations. They provide an opportunity to clarify what behaviors are most valued by managers and how trainees can best spend their time and energy on skill implementation. This helps to explain the success of previous research showing that greater supervisor support results in significantly higher training usage and more positive perceptions of relevance (e.g. Birdi et al., 1997; Brinkerhoff and Montesino, 1995). Action plans as implemented in these cases increase trainee self-efficacy by helping learners envision the behaviors required for successful implementation. This increased self-confidence is important for promoting transfer (e.g. Facteau et al., 1995). The peer meeting and technical support activities described in these cases support the work of Cromwell and Kolb (2004) and Tracey et al. (1995). These meetings show how a peer support network can be formed to supply trainees with information and social exchange without imposing an overwhelming time burden on participants. However, these activities also increase transfer by helping trainees manage perceptions of the risk associated with changing behavior. Participants frequently report feelings of relief as a result of having access to a network of peers who are available for advice and assistance if faced with difficulty when implementing the training. The performance assessments described illustrate how trainee motivation is positively affected by follow-up. Motivation is increased not only because assessment signals to the participants that the organization takes the training seriously, it also helps the trainee to see skill acquisition as a developmental tool that will benefit them personally (e.g. Tyson and Ward, 2004). 
In general, these cases illustrate how a positive climate can be created to support an organization's training effort. Rouiller and Goldstein (1993) noted the importance of climate and called for the development of concrete managerial actions that create time for learning, provide guidance, and encourage transfer of learning to new situations. We believe the follow-up actions described here are a positive step in this direction.

These cases also suggest that the cost of follow-up does not have to be large to produce important gains. Action plans, peer meetings, and supervisory consultations can be implemented with minimal cost and represent good value especially given their

potential to increase return on training dollars invested. These cases also suggest that time demands on managers can be minimised. Vendors and consultants can aid in performance assessment and technical support and can provide valuable feedback and transfer support while minimizing demands on employee time.

Given the potential improvements to operations and employee morale, every training program should have a strategy for promoting transfer. The techniques considered here work to improve trainees' cognitive understanding of the material and willingness to make behavioral changes on-the-job. Follow-up activities easily pay for themselves not only in direct operational improvement but in terms of enhanced morale and communication as well.

\section{References}

Alvarez, K., Salas, E. and Garofano, C.M. (2004), "An integrated model of training evaluation and effectiveness”, Human Resource Development Review, Vol. 3 No. 4, pp. 385-416.

Arthur, W., Bennett, W., Edens, P.S. and Bell, S.T. (2003), "Effectiveness of training in organizations: a meta-analysis of design and evaluation features", Journal of Applied Psychology, Vol. 88 No. 2, pp. 234-45.

Axtell, C.M., Maitlis, S. and Yearta, S.K. (1997), "Predicting immediate and longer-term transfer of training”, Personnel Review, Vol. 26 No. 3, pp. 201-13.

Baldwin, T.T. and Ford, J.K. (1988), "Transfer of training: a review and directions for future research", Personnel Psychology, Vol. 41 No. 1, pp. 63-105.

Bersin, J. (2006), “Companies still struggle to tie training to business goals”, Training, Vol. 43 No. 10 , pp. $22-3$.

Birdi, K., Allan, C. and Warr, P. (1997), "Correlates of perceived outcomes of four types of employee development activity”, Journal of Applied Psychology, Vol. 82 No. 6, pp. 845-57.

Brinkerhoff, R.O. and Montesino, M.U. (1995), "Partnerships for training transfer: lessons from a corporate study”, Human Resource Development Quarterly, Vol. 6 No. 3, pp. 263-74.

Broad, M.L. and Newstrom, J. (1992), Transfer of Training: Action-packed Strategies to Ensure Payoff from Training Investments, Addison-Wesley, Reading, MA.

Bunch, K.J. (2007), "Training failure as a consequence of organizational culture", Human Resource Development Review, Vol. 6 No. 2, pp. 142-63.

Burke, L.A. and Baldwin, T.T. (1999), "Workforce training transfer: a study of the effect of relapse prevention training and transfer", Human Resource Management, Vol. 38 No. 3, pp. $227-42$.

Burke, L.A. and Hutchins, H.M. (2007), "Training transfer: an integrative literature review", Human Resource Development Review, Vol. 6 No. 3, pp. 263-96. 
Burke, L.A. and Hutchins, H.M. (2008), "A study of best practices in training transfer and proposed model of transfer", Human Resource Development Quarterly, Vol. 19 No. 2, pp. 107-28.

Burke, M.J., Sarpy, S.A., Smith-Crowe, K., Chan-Serafin, S., Salvador, R.O. and Islam, G. (2006), "Relative effectiveness of worker safety and health training methods", American Journal of Public Health, Vol. 96 No. 2, pp. 315-24.

Chiaburu, D.S. and Marinova, S.V. (2005), "What predicts skill transfer? An exploratory study of goal orientation, training self-efficacy, and organizational supports", International Journal of Training and Development, Vol. 9 No. 2, pp. 110-23.

Clark, C.S., Dobbins, G.H. and Ladd, R.T. (1993), "Exploratory field study of training motivation: influences of involvement, credibility, and transfer climate", Group and Organization Management, Vol. 18 No. 3, pp. 292-307.

Colquitt, J.A., LePine, J.A. and Noe, R.A. (2000), "Toward an integrative theory of training motivation: a meta-analytic path analysis of 20 years of research", Journal of Applied Psychology, Vol. 85 No. 5, pp. 678-707.

Cromwell, S.E. and Kolb, J.A. (2004), "An examination of work-environment support factors affecting transfer of supervisory skills training to the workplace", Human Resource Development Quarterly, Vol. 15 No. 4, pp. 449-71.

Drucker, P.F. (1999), "Managing oneself”, Harvard Business Review, Vol. 77, March-April, pp. 65-74.

Drucker, P.F., Dyson, E., Handy, C., Saffo, P. and Senge, P.M. (1997), "Looking ahead: implications of the present", Harvard Business Review, Vol. 75, September-October, pp. 3-10.

Facteau, J.D., Dobbins, G.H., Russell, J.E.A., Ladd, R.T. and Kudisch, J.D. (1995), “The influence of general perceptions of the training environment on pre-training motivation and perceived training transfer", Journal of Management, Vol. 21 No. 1, pp. 1-25.

Fitzpatrick, R. (2001), "The strange case of the transfer of training estimate", The Industrial-Organizational Psychologist, Vol. 39 No. 2, pp. 18-19.

Ford, J.K. and Kozlowski, S.W.J. (Eds) (1997), Improving Training Effectiveness in Work Organizations, Lawrence Erlbaum, Mahwah, NJ.

Ford, J.K. and Weissbein, D.A. (1997), "Transfer of training: an updated review and analysis", Performance Improvement Quarterly, Vol. 10 No. 2, pp. 22-41.

Ford, J.K., Quinones, M., Sego, D. and Sorra, J. (1992), "Factors affecting the opportunity to perform trained tasks on the job”, Personnel Psychology, Vol. 45 No. 2, pp. 511-27.

Gephart, M.A., Marsick, V.J., Van Buren, M.E. and Spiro, M.S. (1996), "Learning organizations come alive", Training and Development, Vol. 50 No. 12, pp. 34-45.

Gilpin-Jackson, Y. and Bushe, G.R. (2007), "Leadership development training transfer: a case study of post-training determinants", Journal of Management Development, Vol. 26 No. 10, pp. 980-1004.

Gist, M.E., Stevens, C.K. and Bavetta, A.G. (1991), "Effects of self-efficacy and post-training intervention on the acquisition and maintenance of complete interpersonal skills", Personnel Psychology, Vol. 44 No. 4, pp. 837-61.

Hatala, J. and Fleming, P.R. (2007), "Making transfer climate visible: utilizing social network analysis to facilitate the transfer of training", Human Resource Development Review, Vol. 6 No. 1, pp. 33-63. 
Hawley, J.D. and Barnard, J.K. (2005), "Work environment characteristics and implications for training transfer: a case study of the nuclear power industry", Human Resource Development International, Vol. 8 No. 1, pp. 65-80.

Holton, E.F. III, Bates, R.A. and Ruona, W.E.A. (2000), "Development of a generalized learning transfer system inventory", Human Resource Development Quarterly, Vol. 11 No. 4, pp. 333-60.

Hutchins, H.M. (2009), "In the trainer's voice: a study of training transfer practices", Performance Improvement Quarterly, Vol. 22 No. 1, pp. 69-93.

Kluger, A.N. and DeNisi, A. (1996), "The effects of feedback interventions on performance: a historical review, a meta-analysis, and a preliminary feedback intervention theory", Psychological Bulletin, Vol. 119 No. 2, pp. 254-84.

Kontoghiorghes, C. (2001), "Factors affecting training effectiveness in the context of the introduction of new technology - a US case study", International Journal of Training and Development, Vol. 5 No. 4, pp. 248-60.

Kraiger, K., McLinden, D. and Casper, W.J. (2004), "Collaborative planning for training impact", Human Resource Management, Vol. 43 No. 4, pp. 337-51.

Leonard, B. (2009), "Economic stimulus bill includes wide-ranging HR-related provisions", $H R$ News, 29 January, Society for Human Resource Management, Alexandria, VA.

Lim, D.H. and Morris, M.L. (2006), "Influence of trainee characteristics, instructional satisfaction, and organizational climate on perceived learning and training transfer", Human Resource Development Quarterly, Vol. 17 No. 1, pp. 85-115.

Mathieu, J.E., Tannenbaum, S.I. and Salas, E. (1992), "Influences of individual and situational characteristics on measures of training effectiveness", Academy of Management Journal, Vol. 35 No. 4, pp. 828-47.

Montesino, M.U. (2002), "Strategic alignment of training, transfer-enhancing behaviors, and training usage: a post-training study", Human Resource Development Quarterly, Vol. 13 No. 1, pp. 89-108.

O'Leonard, K. (2008), The 2008 Corporate Learning Factbook: Benchmarks, Facts, and Analysis in US Corporate Learning and Development, Bersin and Associates, Oakland, CA.

Olsen, J.H. Jr (1998), “The evaluation and enhancement of training transfer”, International Journal of Training and Development, Vol. 2 No. 1, pp. 61-75.

Robinson, D.G. and Robinson, J.C. (1989), Training for Impact: How to Link Training to Business Needs and Measure the Results, Jossey-Bass, San Francisco, CA.

Rossett, A. (1997), "It was a great class, but ...", Training and Development, Vol. 51 No. 7, pp. 18-24.

Rouiller, J.Z. and Goldstein, I.L. (1993), "The relationship between organizational transfer climate and positive transfer of training", Human Resource Development Quarterly, Vol. 4 No. 4, pp. 377-90.

Saks, A.M. and Belcourt, M. (2006), "An investigation of training activities and transfer of training in organizations", Human Resource Management, Vol. 45 No. 4, pp. 629-48.

Salas, E. and Cannon-Bowers, J.A. (2001), "The science of training: a decade of progress", Annual Review of Psychology, Vol. 52, pp. 471-99.

Salas, E., Rozell, D., Mullen, B. and Driskell, J.E. (1999), "The effect of team building on performance: an integration”, Small Group Research, Vol. 30 No. 3, pp. 309-29.

Salinger, R.D. and Deming, B.S. (1982), "Practical strategies for evaluating training", Training and Development Journal, Vol. 36, August, pp. 20-26, 28/29. 
Senge, P.M. (1995), The Fifth Discipline, Doubleday, New York, NY.

Tannenbaum, S.I. and Yukl, G. (1992), "Training and development in work organizations", Annual Review of Psychology, Vol. 43, pp. 399-441.

Tracey, J.B., Tannenbaum, S.I. and Kavanagh, M.J. (1995), “Applying trained skills on the job: the importance of the work environment", Journal of Applied Psychology, Vol. 80 No. 2 , pp. 239-52.

Tyson, S. and Ward, P. (2004), "The use of 360-degree feedback technique in the evaluation of management development", Management Learning, Vol. 35 No. 2, pp. 205-23.

Webster, J. and Martocchio, J.J. (1993), “Turning work into play: implications for microcomputer software training", Journal of Management, Vol. 19 No. 1, pp. 127-46.

Wexley, K.N. and Baldwin, T.T. (1986), "Post-training strategies for facilitating positive transfer: an empirical exploration", Academy of Management Journal, Vol. 29 No. 3, pp. 503-20.

Yamnill, S. and McLean, G.N. (2001), "Theories supporting transfer of training", Human Resource Development Quarterly, Vol. 12 No. 2, pp. 195-208.

Yorks, L., Beechler, S. and Ciporen, R. (2007), "Enhancing the impact of an open-enrollment executive program through assessment", Academy of Management Learning and Education, Vol. 6 No. 3, pp. 310-20.

Post-print standardized by MSL Academic Endeavors, the imprint of the Michael Schwartz Library at Cleveland State University, 2015 